\title{
The Relationship Between Treasury Cash Management and Monetary Policies
}

\author{
Chang Tang*, Qiuyan Man, Qinyuan Zhao \\ School of Public Finance and Tax, Central University of Finance and Economics, Beijing, China
}

Email address:

tchang@163.com (Chang Tang)

${ }^{*}$ Corresponding author

\section{To cite this article:}

Chang Tang, Qiuyan Man, Qinyuan Zhao. The Relationship Between Treasury Cash Management and Monetary Policies. Journal of Finance and Accounting. Vol. 7, No. 3, 2019, pp. 88-94. doi: 10.11648/j.jfa.20190703.13

Received: April 21, 2019; Accepted: June 18, 2019; Published: June 29, 2019

\begin{abstract}
Treasury cash management interrelates with the budget implementation, monetary policies, debt management and financial market development. The relationship between the treasury cash management and the monetary policies is the most crucial and most primary one. Tax revenues are deposited in treasury account that affects monetary policy. At the same time, the treasury cash will also have an impact on the money market through fiscal expenditure and market operation. The relationship between the treasury cash management and monetary policy in developed countries has formed a relatively stable institutionalized mechanism. However, the treasury reform in developing countries faces various difficulties. It is very important to sort out the relationship between the treasury cash management and monetary policy for the reform of the national treasury system in developing countries. This paper takes China as the research object and discusses the relationship between the treasury cash management and the monetary policies. The analysis results show that the treasury cash management mainly affects the monetary policies by the stock funds, and different effects are accounting for corresponding investment methods. Investment in the fixed-term deposits in the commercial banks, due to the existence of collateral effect that it cannot lead to any equivalent increments of the liquidity in the commercial banks. Whereas investment in the monetary market may have an impact on short-term interest rates.
\end{abstract}

Keywords: Treasury Funds, Cash Management, Monetary Policies, Policy Coordination

\section{The Influential Mechanism of Treasury Cash Management on Monetary Policies}

The effect of the treasury cash management on the monetary policies mainly refers to the effect of investment operations on the money supply and the monetary market interest rates. The influential level depends on the source of the national treasury funds during the investment process and the mode of investment operation [1].

\subsection{The Effects of Stock Funds and Temporarily Idle Funds on Monetary Policies}

In the treasury cash investment operation, the sources of treasury stock funds or temporarily idle funds have different effects on the monetary policies [2]. The treasury stock is the financing deposition funds at the treasury single account (TSA), when implementing the target cash balance management, the stock funds above or below the target level will result in the net inflow or net outflow of the TSA. Therefore, it plays a role similar to the one of the monetary policy operation, and has a greater effect on the financial system.

The temporarily idle funds are the temporarily increment at the TSA due to the operational gap between fiscal revenue and expenditure with treasury cash management [3]. The fiscal revenue composes of corporate tax, individual income tax, and non-revenue receipt. Before the enterprises or individuals pay taxes, these funds are generally existing in the commercial banking system [4]. After tax paying, the funds are flowing into the TSA in the central bank from the commercial bank accounts of enterprises or individuals in the forms of tax and non-tax. In order to maintain the financial stability of the target balance when managing the financing 
deposition funds balance, the treasury cash authority will implement a market-oriented investment of the temporarily idle funds, whether in the form of commercial bank deposits or investment in the monetary market, which will eventually flow back into the commercial banking system, only changing in the owners and the forms of the funds [5]. Therefore, the temporarily idle funds mainly cause the transfer of ownership of funds within the banking system, and the total amount of funds in the economic system has not changed, and do not have substantial impact on monetary policies (Figure 1).

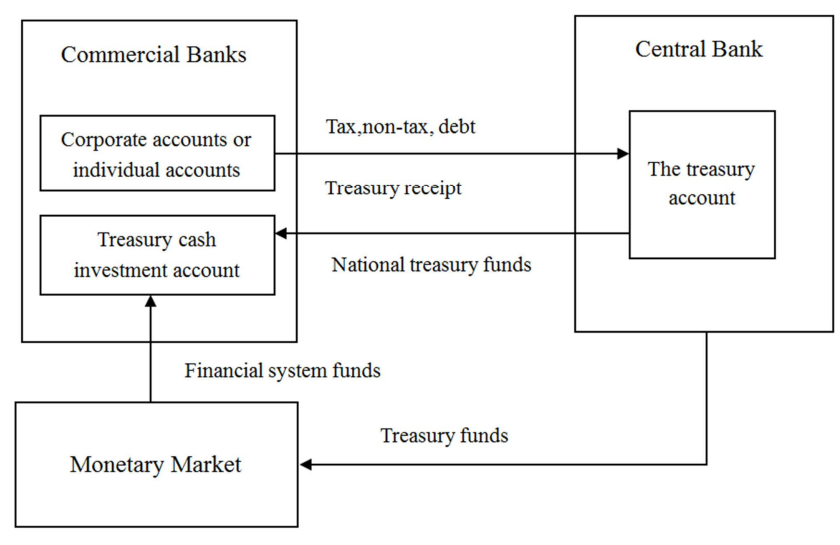

Figure 1. The temporarily idle fund flow diagram.

\subsection{The Effect of Different Investment Models on Monetary Policies}

Different investment models play different roles to the monetary policies, investing in the fixed-term deposits in the commercial banks may have bigger impact on commercial banking system, whereas investing in the monetary market may have more effects on interest rates of the monetary market [6].

When assessing the treasury funds investment in the fixed-term deposits in the commercial banks, it must consider the collateral effect [7]. Whether the source of treasury cash investment in the fixed-term deposits is from the stock funds or the incremental funds, in order to ensure the security of fiscal funds, the common practice of investing the treasury funds in the commercial banks requires the collateral value equivalent to $100 \%-120 \%$ of these funds, and the collateral is generally bonds outstanding with high-credit grade (mainly national debt). Since the collateral is of equivalent or excessive value that the commercial banks cannot use these bonds as collateral to borrow money from inter-bank market, it will shrink the liquidity of the banks in where the treasury cash deposits [8]. In addition, the commercial banks that do not have sufficient amounts of national debt will have to use their funds to purchase required amount of national debt, which will lead to a direct reduction in the liquidity of the commercial banks, offsetting the incremental effect of the national treasury funds on the commercial bank deposits to certain extent [9]. That is to say, the collateral effect will be inhibitive to the fixed-term deposits of the treasury funds increase an equivalent liquidity for the commercial banks, and cannot lead to an equivalent increment in loans [10].

If the treasury funds choose to invest in the monetary market, which will eventually inject liquidity into the commercial banking system, but may have an impact on interest rates of the monetary market. The investment of national treasury funds into the monetary market will affect the short-term capital supply and demand in the monetary market, which may affect the short-term interest rates of the monetary market [11]. The significances of these effects are dependent on factors such as the market share of the funds scale, the investment period and the funds concentration. If the funds scale of investment of treasury funds in the monetary market is relatively small compared to the market capacity, then the injected liquidity will not significantly affect the interest rates of monetary market, but if the funds scale is relatively big, it may cause changes of the liquidity of the monetary market in-depth and in-breadth, causing fluctuations of short-term interest rates in the monetary market [12].

Table 1. The effect of investment operation of treasury funds on the monetary policies.

\begin{tabular}{|c|c|c|}
\hline & Investment in commercial banks & Investment in monetary market \\
\hline The stock funds & affect money supply, similar to the monetary policy tools & $\begin{array}{l}\text { affect money supply, affect capital supply and demand in } \\
\text { monetary market }\end{array}$ \\
\hline The temporarily idle funds & do not affect money supply, play a role of redistribution & $\begin{array}{l}\text { do not affect money supply, but affect capital supply and } \\
\text { demand in monetary market }\end{array}$ \\
\hline
\end{tabular}

It should be understood that in the cash management process, the stock funds and the temporarily idle funds coexist, and treasury cash investment has a comprehensive impact on the monetary policies [13]. After establishing the financing deposition target balance, the investment of the treasury cash management is mainly the incremental funds, so that the treasury cash management has little effect on the monetary policies. Therefore, the next part focuses on analyzing the impact of the reduction of stock funds on the monetary policies.

\section{The Effect of China's Treasury Cash Management on the Monetary Policies}

To implement the target cash balance management mechanism, it is necessary to set the financing deposition target balance and maintain the financing deposition balance at the target level through investment and financing operations. In many developing countries, there is a need to reduce the treasury stock funds in the case of higher cash balances [14]. There is a case analysis of how China's 
treasury stock funds reduction impacts on the money supply and the monetary market.

\subsection{The Impact of Reduction of National Stock Funds on the Money Supply}

Since the treasury funds will eventually flow into the commercial banking system regardless of it is invested in the fixed-term deposits in the commercial banks or the monetary market, it can directly analyze the impact of reducing the treasury stock funds on the money supply.

\subsubsection{Scale and Time Assumptions for the Reduction of Treasury Stock Funds}

To assess the impact of the reduction in the treasury stock funds on the money supply, it is necessary to make assumptions about the extent and speed of the reduction of treasury stock funds. Given that China's treasury cash management separates the central treasury from the local treasury, it is necessary to consider the effects of reduction of central treasury stocks and local treasury stocks on the monetary policies respectively. From 2010 to 2017, the average monthly cash balance of China's central treasury is about 700 billion yuan, and the monthly average cash balance of local treasury is about 2.5 billion yuan. Assuming that the central treasury stock funds target cash balance is 170 billion yuan $^{1}$, that is, the central treasury stock funds have to be reduced by 530 billion yuan, and the local treasury stock funds target cash balance is 782 billion yuan, that is, the local treasury stock funds need to be reduced by 171 billion yuan, and the total reduction of national treasury stock funds is 2 , 240 billion yuan. It is necessary to make assumptions about the time when the treasury stock funds need to be reduced. Assuming that the treasury stock funds will be gradually reduced to the target cash balance in the next three years, then nearly 750 billion yuan of treasury stock funds will be reduced each year. If considering the implementation difficulties in the local financing deposition target balance management, it is assumed that the central government first implements the financing deposition target balance management, and the local governments implement the financing deposition target balance management afterwards (at least the local governments would not simultaneously implement the financing deposition target balance), then there will be even smaller reduction of treasury stock funds needed in the next three years.

\subsubsection{The Effect of the Reduction of Treasury Stock Funds on the Money Supply}

The outflow of treasury stock funds from the treasury account in the central back is equivalent to the release of the monetary base. Therefore, according to the assumptions, the reduction of treasury stock funds in the next three years will increase the monetary base by 750 billion yuan per year.

\footnotetext{
1 Since China's treasury cash management model merely has the fixed-term deposits in the commercial banks, it is suitable to use the VaR model to measure and calculate the target balance. The target balance here is measured and calculated by VaR.
}

According to the quantity equation of money, the money supply is equal to the monetary base multiplied by the monetary multiplier, assuming that the broad monetary multiplier remains still for the next three years, equal to the average of 5.04 over the three years from 2016 to 2018, then in the next three years, due to the annual reduction of treasury stock funds which results in the increase of broad money supply by about 378 billion yuan.

In order to measure the proportion of the increment of money supply which is due to the reduction of treasury stock funds in the overall money supply, it is necessary to make a simple forecast of the broad money supply (M2) in the next three years. From 2011 to 2018, China's broad money supply grew at an average annual rate of $12.7 \%{ }^{2}$. Assuming that it will continue to grow at the rate of $12.7 \%$ in the next three years, the broad money supply in the next three years will be 188.9 trillion and 212.9 trillion and 240 trillion yuan respectively. Correspondingly, the proportion of the increased amount of broad money supply due to the reduction of treasury stock funds in the next three years in the overall money supply in the three year, is accounting for $2.00 \%$, $1.78 \%$, and $1.58 \%$ respectively. Therefore, if there are annual reduction of 750 billion yuan of treasury stock funds in three years, the increment of money supply resulted over the entire money supply is only accounting for about $1.8 \%$. If considering the local implementation of financing deposition target balance management would be hysteretic, combing with the inhibiting factor of the collateral effect on the treasury fund credit expansion, then the implementation of financing deposition target balance management in the future will lead to a smaller impact of monetary release on the money supply.

\subsection{The Effect of Treasury Stock Funds Investment in Monetary Market on Monetary Policies}

Besides the fixed-term deposits in commercial banks, it can invest the treasury stock funds in the monetary market through national debt repurchase and reverse bond repurchase. According to the previous analyses, whether the investment of treasury cash in the monetary market has an impact on monetary policies depends on whether the amount of funds is sufficient to influence the supply and demand of the monetary market [15]. Based on the fact that China's monetary market is underdeveloped and the banking system is relatively developed, it has resulted that the market-oriented operation of China's treasury cash management mainly is the deposition in commercial banks as the major investment tool. Of course, in order to maximize the return on investment, it is recommended to actively explore diversified investments in the monetary market. Assuming that a quarter of the annual reduction of 750 billion yuan in the treasury stock funds, that is, 250 billion yuan are invested in the monetary market, next it will analysis the impact of the reduction of treasury stock funds

\footnotetext{
2 Since 2011, China has been consistently implementing a "steady and neutral" monetary policy, so the data selected is from 2011 as the starting point.
} 
on the monetary market through national debt repurchase and reverse bonds repurchase.

\subsubsection{The Impact of Reduction of Treasury Stock Funds on the Monetary Market Through National Debt Repurchase}

In order to assess the impact of the annual repurchase of 250 billion national debt paid by the national treasury stock funds on the government bonds market in the next three years it is necessary to forecast the balance of national debt in the next three years. From 2006 to 2018, the average annual growth rate of national debt balance is $23 \%$. Assuming that the average annual growth rate will still in the next three years, the balance of national debt from 2019 to 2021 will reach 34.15 trillion, 42.01 trillion, and 51.67 trillion yuan, respectively. The ratio of 250 billion yuan to the balance of national debt is $0.73 \%, 0.60 \%$, and $0.48 \%$, respectively, which are relatively small. If the 250 billion yuan of fiscal funds is paid in multiply times that divide the annual payment into several payments, such as once a month, then each payment is only about 21 billion, accounting for $0.04 \% \sim 0.06 \%$ of the entire government bonds market, and the impact on the government bonds market will be further diminished.

\subsubsection{The Impact of Reduction of Treasury Stock Funds on the Monetary Market Through Reverse Bonds Repurchase}

Similar to the analysis of national debt repurchase, it can further analyze the impact of the reduction of national treasury stock funds on the monetary market through reverse bonds repurchase. The operation of reverse bonds repurchases paid by the treasury cash is most appropriated in the form of inter-bank pledged repo reverse repurchase. Therefore, the inter-bank pledged repo market will be the analysis object in the next.

From 2004 to 2018, the average annual growth rate of inter-bank pledged repo balance in China was $30.3 \%$. Assuming that this average growth rate will remains in the next three years, the inter-bank pledged repo balances from 2019 to 2021 will be 7.36 trillion yuan, 9.59 trillion yuan, 12.5 trillion yuan, respectively, and the ratio of 250 billion yuan of funds over pledged repo balance is accounting for $3.40 \%, 2.61 \%, 2.00 \%$, respectively, which are relatively small. If the 250 billion yuan of fiscal funds is paid in multiply times that divide the annual payment into several payments, such as once a month, then each payment is only about 21 billion, accounting for $0.17 \% \sim 0.28 \%$ of the entire pledged repo market, and the impact on the pledged repo market will be further diminished.

In order to more accurately analyze the impact of the treasury cash on the monetary policies through the reverse bonds repurchase in the monetary market, it further uses the impulse response analysis in the measurement method to analyze the impulse effect of an additional amount of funds entered the pledged repo market by simulating the effect of the treasury stock funds investing in reserve bonds repurchase on the interest rates of monetary market. The sample data of the pledged repo market includes the pledged repo trading volume (T_REP) and the pledged repo average interest rate (I REP) from January 2003 to December 2018, in order to eliminate the effects of multicollinearity and autocorrelation, we put the two variables in the first-order difference equation.

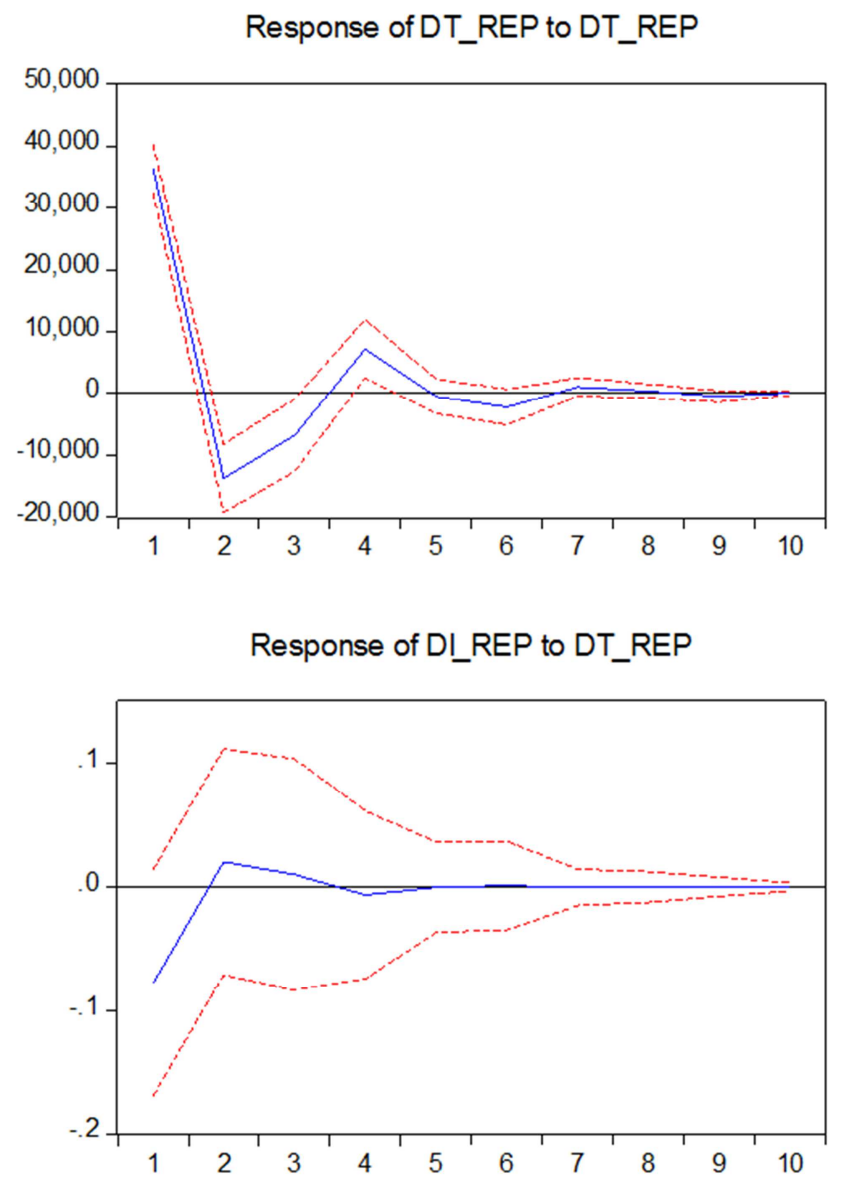

Figure 2. Pledged repo trading volume and impulse response process of repo rate.

As shown in Figure 2, when an additional amount of funds enters the pledged repo market, at this particular time the trading volume of the market will increase substantially. In the following month, the trading volume of transactions begins to plummet and declines, and in the second month drops to the bottom. Subsequently, the trading volume begins to recovery, and in the fourth month it ramps up to a slightly higher than the original level and reaches the maximum. From the fifth month onwards, the trading volume slightly fluctuates around the original level, and in the seventh month, the market has digested the unexpected impact of this additional amount of funds. For the repo rate, it declines sharply by the additional funds' entry, then rises slightly, which slowly declines after reaching the peak in the second month, and basically has digested the impact of the additional funds after the fourth month. Impact. It shows that the impact of entry of an additional amount of funds in the pledged repo market only causes a small fluctuation in the short term, but it will completely be digested in a short period, which 
indicates that the national treasury stock funds investing in reverse bonds repurchase has a small impact, so it is appropriate to carry out this operation. In addition, in order to avoid a substantial impact of the entry of treasury stock funds in the financial market in the short term, it must consider the market capacity when the treasury management department investing and financing of the treasury funds, injecting funds in stages according to the plan, in order to diminish the impact of the treasury funds on the monetary market.

The above analysis focuses on the impact of the reduction of the treasury stock funds in the monetary market on the monetary policies. Of course, in the process of treasury cash management, the amount of funds invested in monetary market depends on the development of the monetary market, especially the development of short-term government bonds market. Before the short-term government bonds market expanded, it is expected that the investment methods of China's treasury cash will mainly invest in the fixed-term deposits in commercial banks, and the scale of investment in national debt repurchase in the monetary market will at small scale. However, when the monetary market continues to expand, the scale of national treasury cash investment through monetary market also increases. At that time, it can diminish the impact of the treasury cash on the monetary market by controlling the investment type, duration, and concentration of counterparties.

\section{Improve the Relationship Between the Treasury Cash Management and Monetary Policies}

\subsection{Defining the Treasury Cash Management Duties}

At present, according the laws, China stipulates that the Ministry of Finance and the People's Bank of China perform the treasury cash management, the People's Bank of China performs the function of "managing treasury". The Ministry of Finance is responsible for forecasting the national treasury cash and formulating operational plans for the balance based on the forecast results, and the People's Bank of China is responsible for the monitoring of the monetary market [16]. Although at present, the People's Bank of China has certain supervision functions for the treasury funds for some reasons, but the jointly management of the treasury cash by the Ministry of Finance and the People's Bank of China restricts the flexibility and effectiveness of the treasury cash management implemented by the by the Ministry of Finance [17]. Moreover, form the foreign government experiences or on the theoretical analysis, the main body of treasury cash management should be the Ministry of Finance. The fiscal and the central bank are more agency relations that the central bank should specialize in formulating monetary policies, and have not financial functions.

Regarding the division of management responsibilities of the treasury cash, combined with the current situation, it is recommended that the Ministry of Finance take the leading role in the treasury cash management with the cooperative support from the People's Bank of China. This management mode can maintain the independence of the treasury cash management and monetary policies, satisfy their respective requirements, and will not disturb the market. With the development of China's centralized payment system of treasury and the TSA management, the Ministry of Finance can perform effective supervision of the treasury cash in the case of the People's Bank of China off the supervisory duty. Then the Ministry of Finance would full control the treasury cash management, and the relationship between the Ministry of Finance and the People's Bank become a real agency relationship, so that the Ministry of Finance has higher autonomy, giving the monetary policies stronger independence, and realizing a win-win of the efficient cash management and well implemented monetary policies.

\subsection{Coordination in the Adjustment of the Treasury Cash Balances}

By setting a steady treasury cash balances, it can diminish the impact of treasury cash management on monetary policies. This requires a strengthening information communication between the treasury financial authority and the central bank through a treasury single account.

First is to the setting and adjustment of the treasury cash balances. Setting a steady target balance can well diminish the impact of treasury cash management on the monetary policies, which requires a TSA to strengthen the information communication between the treasury financial authority and the central bank. For this purpose, the People's Bank of China needs to collect and sort out the changes in the government deposits and the end-of-day balance in the TSA, focusing on the analysis and forecasting of the treasury cash flow, and sort out the amount and time-point data of the treasury cash inflows and outflows, in order to prepare for the forecasting. The Ministry of Finance also needs to implement annual, quarterly, and monthly statistical forecasting on its own.

Both the Ministry of Finance and the People's Bank need to share information through an electronic information platform, and establish cash flow statistics and forecasting methods to jointly forecast cash flows and estimate and adjust the treasury cash balances. The cooperation of the two can improve the accuracy of the treasury cash flow forecast and determine the appropriate treasury cash balances, which is the basis for the subsequent investment and financing of the treasury cash balance. In the actual operation, the main information shared shall include the daily cash balance and cash flow history database of the TSA, and the weekly and daily information record of the treasury cash balance changes.

Second is to cooperate closely in the process of reducing the treasury stock funds. In the process of implementing the management of financing deposition target balance, at least there are hundreds of billions of treasury funds will be transferred to the commercial banking system in the next few years. In order to avoid any adverse impact on the monetary 
policies and macro economy, the treasury authority should perform consultations with the People's Bank of China on a regular basis, establishing an effective negotiation and communication mechanism, and according to the current macroeconomic and monetary environment choose the appropriate timing.

\subsection{Coordination and Cooperation in the Investment and Financing of the Treasury Funds}

First, it should clear the style of coordination. The specific coordination of the treasury cash management and the central bank includes active coordination and passive coordination [18]. Active coordination means that the fiscal treasury department adapts to the monetary policies by adjusting specific planning operation. For example, when the central bank implements a tight monetary policy, the fiscal treasury would delay or cancel the investment plan that should be carried out to cope with the implementation of monetary policy. Passive coordination means that the Ministry of Finance conducts the treasury cash investment and financing operation according to its own plans, regardless of the monetary policies, but communicates with the central bank before the implementation of the plan, so that the central bank can consider the impact of the treasury cash management when formulating monetary policies, after all it will achieve the initial policy objectives through the plan adjustment.

Both coordination can diminish the impact of the treasury cash management on the monetary policies, and support the monetary policies to achieve the expected objectives. But the difference is that under active coordination, the Ministry of Finance will lose some benefits it should have, and inefficient use of funds, resulting in additional loss of economic efficiency. While in the passive coordination, the Ministry of Finance can operate the treasury cash according to the principles of safety, liquidity and profitability, which brings benefits to the treasury cash management, reduces or even eliminates the loss of economic efficiency. Then the central bank will adjust the monetary policy arrangements based on changes in the treasury cash. Therefore, the passive coordination is better than the active coordination. According to the current situation in China, a passive coordination mode should be adopted.

Second, it should strengthen information exchange and consultation between the fiscal department and the central bank. The fiscal department shall communicate with the central bank the data of the cash flow forecast, the bond issue scale and plan, the transaction method, tools, targets, time points and amount of the treasury cash management before the operation; the central bank shall combine self-forecasting and information provided by the fiscal department to determine the liquidity in the future market, and considerate the changes in the treasury cash balance when formulating monetary policies. After all, through timely information communication, it can ensure that the central bank takes into account the changes in the treasury cash balance when formulating monetary policies, which is conducive for the central bank to adopt appropriate monetary policy operations, and reduce the impact of the treasury cash on the liquidity of the commercial banking system. It can achieve the benefits of the treasury cash investment, and also ensure the coordination of fiscal treasury and the monetary policies.

\section{Conclusion}

The impact of treasury cash management on monetary policy mainly affects monetary policy through two channels: money supply and money market interest rate. The extent of the impact depends mainly on the source of the Chinese capital in the investment process and the way the investment operates. From the perspective of funding sources, stock funds have a greater impact on monetary policy, and the impact of intermittent funds on monetary policy is almost negligible. From the perspective of investment methods, investing in the commercial banking system will not lead to significant changes in the amount of loans, and investment in the money market will cause fluctuations in short-term interest rates in the money market. It is necessary to improve the relationship between treasury cash management and monetary policy. Reform should be carried out in three aspects. First, clarify the treasury cash management responsibilities. Second, effective coordination in the management of the balance of the stock; third, coordination in the operation of the treasury fund investment and financing.

\section{References}

[1] Mike Williams, (2004), Government Cash Management: Good and $\mathrm{Bad}$ Practice. Available via Internet: http://www.mj-w.net/cac_gov_cash.html.

[2] Rascoe, Mary (2007), Managing the Nation's Money, presentation made at the sixteenth Annual Government Financial Management Conference. Financial Management Service, U.S. Department of the Treasury, Washington, D. C.

[3] Jianqi Chen, Jinshan L (2008). Influence Mechanism and Evidence of Treasury Cash on Money Supply Policy: A Study Based on the Background of the Central Bank of China's Central Bank Managers. World Economy, 07, 44-56.

[4] Xiaorong Liu (2017), Current Situation, Problems and Countermeasures of China's Treasury Cash Management. Financial Accounting, 03, 69-74.

[5] Xueyang Wang (2005), The Choice of Treasury Cash Management Method. China Finance. 7, 41-42.

[6] M Williams (2014), Goverment Cash Management: Good and Bad Practice. Springer Singapore, 17-21.

[7] Jianqi Chen (2007), Study on the Influence of Treasury Funds on Monetary Policy Effect. Doctoral Dissertation, Zhejiang University.

[8] Hald, E. C. (1956), Monetary Aspects of Changes in Treasury Cash Balances. Southern Economic Journal, 22,: 448-456.

[9] YinBin $\mathrm{Mu}$ (2006), Goverment cash Management: Good Practice \& Capacity - Building Framework [J]. Ssrm Electronic Journal, 29-33. 
[10] Kinley D. (1908), The Relation of the United States Treasury to the Money Market [J]. American Economic Association Quarterly, 3rd Series, 9, 199-211.

[11] Zhenhai Liu, Shan Ji (2018), Budget Performance Management Reform from the Perspective of Treasury. China Finance, 24, 100-101.

[12] Lynch, T. D., Shamsub, H.\&Onwujuba (2002),. A Strategy Budgeting to Prevent Losses in Local Government Investment Pools, Public 22, 60-79.

[13] Tianlong Ma (2019), Research on the Coordination of Central Bank Manager's Treasury and Budget Performance Management. Sub National Fiscal Research, 04, 45-51.

[14] Cooper. S. K (1973), Idle Cash Balances of State and Local Governments: An Estimation Techniques, Nebraska Journal of Economics \& Business, 12, 21-21.
[15] Qinghai Yuan (2012), Research on the Economic Effect of Chinese Treasury Funds, Doctoral Dissertation, Jilin University.

[16] Taozhen Huang, Liyuan Yin (2018), Game Analysis of the Relationship between Finance and Bank in the Treasury Centralized Payment System. Sub National Fiscal Research, 04, 61-65.

[17] Qing Wang (2013), Analysis on the Coordination of Cash Management and Monetary Policy in the Treasury, New Finance, 7, 16-19.

[18] Xiaoping Yang (2005), The Impact of Treasury Funds on the Implementation of Monetary Policy, Review of Economic Research, 71. 